\title{
Violence in American Popular Culture: The Myth of the Vigilante in Chuck Palahniuk's Fight Club and Sam Ismail's Mr. Robot
}

\author{
SELMA DJABALLAH \\ Faculty of Foreign Languages \\ Department of English \\ University of Algiers II, Algeria
}

\begin{abstract}
Popular culture presents new dimensions for cultural and social studies through several artistic products. Different themes and symbols in literature and movie studies provide fresh materials for cultural studies and literary criticism. The issue of violence in American popular culture, in particular, is depicted in many artistic works of fiction. This article focuses on the depiction of violence in Chuck Palahniuk's novel Fight Club (1996) and Sam Ismail's television series $M r$. Robot (2015). More specifically, it analyzes the depiction of violence in these two narratives through the myth of the vigilante, a theory developed by the American critic John Cawelti. To reach its final results, this article attempts first to investigate the reasons and origins of violence as caused by postmodern conditions. Second, it draws a conclusion on the development of violence in American popular culture by studying the evolution of the myth of the vigilante from Fight Club to $M r$. Robot.
\end{abstract}

Keywords: Chuck Palahniuk, Fight Club, Mr. Robot, myth, Sam Ismail

Cite as: DJABALLAH, S. (2020). Violence in American Popular Culture: The Myth of the Vigilante in Chuck Palahniuk's Fight Club and Sam Ismail's Mr. Robot. Arab World English Journal for Translation \& Literary Studies 4 (1) 171 -183.

DOI: http://dx.doi.org/10.24093/awejtls/vol4no1.14 